\title{
Optimum concrete compression strength using bio-enzyme
}

\author{
Tony Hartono Bagio ${ }^{1,}$, Makno Basoeki ${ }^{2}$, Julistyana Tistogondo $^{1}$, and Sofyan Ali Pradana ${ }^{1}$ \\ ${ }^{1}$ Narotama University, Surabaya, Indonesia \\ ${ }^{2}$ Engineer of Mirama Consultant, Surabaya, Indonesia
}

\begin{abstract}
To make concrete with high compressive strength and has a certain concrete specifications other than the main concrete materials are also needed concrete mix quality control and other added material is also in line with the current technology of concrete mix that produces concrete with specific characteristics. Addition of bio enzyme on five concrete mixture that will be compared with normal concrete in order to know the optimum level bio-enzyme in concrete to increase the strength of the concrete. Concrete with bio-enzyme $200 \mathrm{ml} / \mathrm{m} 3,400 \mathrm{ml} / \mathrm{m} 3,600 \mathrm{ml} / \mathrm{m} 3$, $800 \mathrm{ml} / \mathrm{m} 3,1000 \mathrm{ml} / \mathrm{m} 3$ and normal concrete. Refer to the crushing test result, its tends to the mathematical model using 4th degree polynomial regression (least quartic), as represent on the attached data series, which is for the design mix $\mathrm{fc}^{\prime}=25 \mathrm{MPa}$ generate optimum value for $33,98 \mathrm{MPa}$, on the bio-additive dosage of $509 \mathrm{ml}$ bio enzymes.
\end{abstract}

\section{Background}

The quality of the concrete is determined by the materials of concrete preparation. In order to make concrete with high compression strength and has a certain concrete specification cannot be obtained simply by mixing cement Portland cement or other types of coarse aggregate, fine aggregate, and water. But it is necessary to also control the quality of the concrete mix. Improving the quality of the concrete mix will increase the compression strength is generated $[6,7]$.

Mixed concrete technology is currently also developing rapidly, many other added material application technologies to produce concrete with the desired characteristics. One way to improve the quality of the concrete mix is to use the added material, either a chemical such as entraining admixture, reducing water in the form of synthetic or organic. On this paper, we would like to introduce our research on improving concrete quality with green technology using bio enzyme, which is not covered yet in current classification A to F of concrete chemical admixtures used.

\footnotetext{
* Corresponding author: tony@narotama.ac.id
} 
The bio enzyme admixture, is a bio-technology product made of organic/natural materials, denatured proteins, biopolymer surfactant and organic minerals which fermented by beneficial microbes [18]. The quality of the concrete is determined by the materials of concrete preparation. To make concrete with high compression strength and has a certain concrete specification cannot be obtained simply by mixing cement Portland cement or other types of coarse aggregate, fine aggregate, and water. But it is necessary to also control the quality of the concrete mix. Improving the quality of the concrete mix will increase the compression strength is generated.

Mixed concrete technology is currently also developing rapidly, many other added material application technologies to produce concrete with the desired characteristics [1]. One way to improve the quality of the concrete mix is to use the added material, either a chemical such as entraining admixture, reducing water in the form of synthetic or organic such as bio enzyme. The bottom line target in develop and research of this Bio-Enzyme product are:

1. Reduce the cement content, means reduce the $\mathrm{CO}_{2}$ emission implicate the eco-friendly impact [18].

2. Reduce the cement content, means reduce the thermal effect of hydration heat, produced the Low Heat Concrete.

3. Reduce the cement content, means reduce the production cost of concrete [18].

4. Another performances of Bio-Enzyme are a microbe which produce micro fibre, reduce the shrinkage crack event eliminate it, these phenomena show on crack pattern of the samples crushing test [18].

\section{Methods}

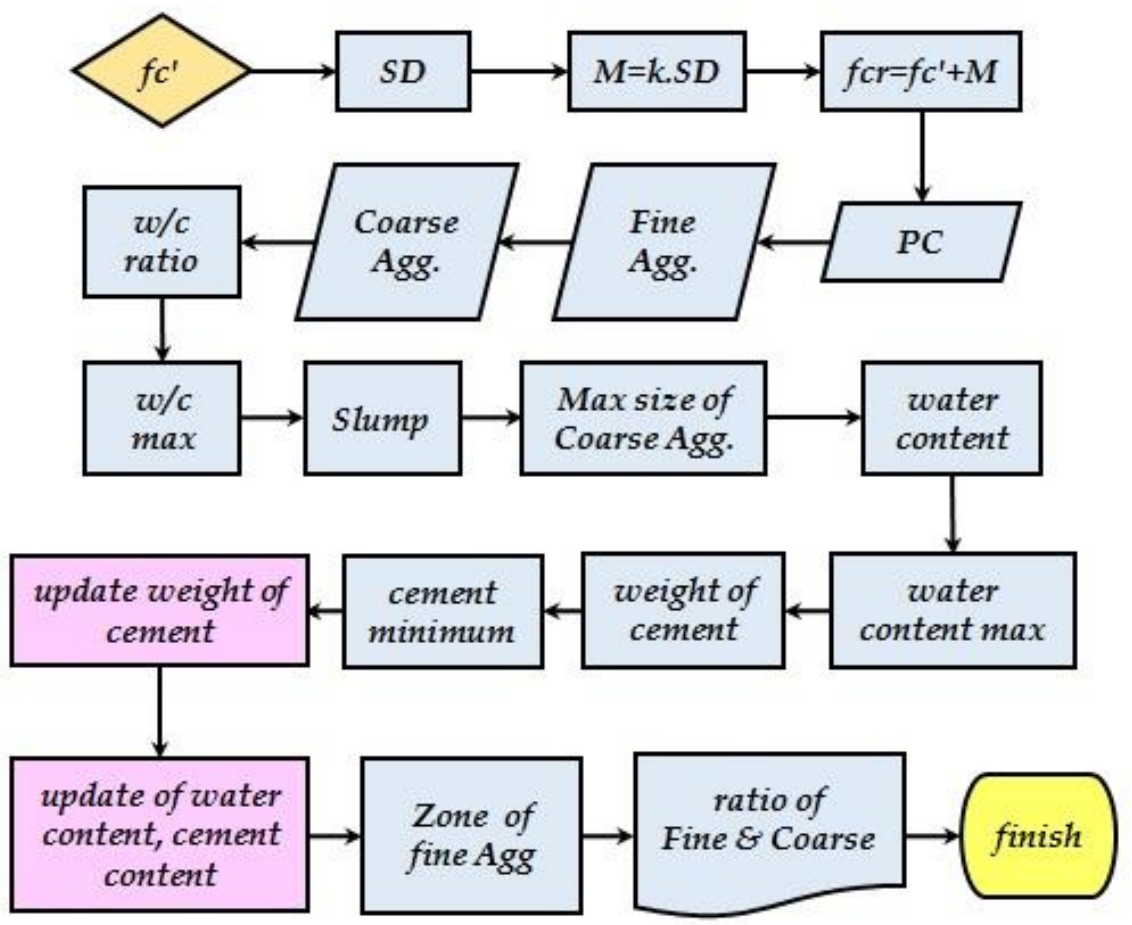

Figure 1. Flow Chart of Mix Design 
Mix design of concrete based on DoE (Department of Environment) from British Standard Code's. Adopted to Indonesian's Code [17] to mix design. The method of mix design shows in Figure 1.

Mix design with initial concrete (normal condition) $f c^{\prime}$ is $25 \mathrm{MPa}$, Portland Cement $=409$ $\mathrm{kg}$, water $=225 \mathrm{~kg}$, fine aggregate $=733 \mathrm{~kg}$, coarse aggregate $=1013 \mathrm{~kg}$. Cylinder testing with 6 types of experiments (type A to F). Find the optimum value of the 5 additional variations with different types of polynomial equations to $R^{2}=1$

\section{Results}

After a physical test $[2,8-16]$ of the material is used, a concrete mortar plan is prepared using the British Standard 8110 Department of Environment (DoE) [3,4,5] method shown in Table 1.

Table 1. Form of Mix Design

\begin{tabular}{|c|l|c|c|}
\hline No. & Description & Data & Unit \\
\hline 1 & fc' (cylinder 28 days) & 25 & $\mathrm{MPa}$ \\
\hline 2 & Standard Deviation & 6 & $\mathrm{MPa}$ \\
\hline 3 & Margin & $1,64 \times$ SD $=9.84$ & $\mathrm{MPa}$ \\
\hline 4 & Target Strength (average) & 35 & $\mathrm{MPa}$ \\
\hline 5 & Types of Portland Cement & OPC & unitless \\
\hline 6 & Types of Coarse Aggregate & Crushed & unitless \\
\hline 7 & Types of Fine Aggregate & Natural & unitless \\
\hline 8 & free water content ratio & 0.55 & unitless \\
\hline 9 & Water cement maximum & 0.6 & unitless \\
\hline 10 & Slump & $150+/-2,(60-180)$ & $\mathrm{mm}$ \\
\hline 11 & Max size Aggregate & 20 & $\mathrm{~mm}$ \\
\hline 12 & Free Water content & 225 & $\mathrm{liter}$ \\
\hline 13 & Cement Content & 409 & $\mathrm{~kg}$ \\
\hline 14 & Cement Content Minimum & 275 & $\mathrm{~kg}$ \\
\hline 15 & Update Free Water Content & 225 & $\mathrm{liter}$ \\
\hline 16 & Zone of Fine Aggregate & Zona II & $\mathrm{unitless}$ \\
\hline 17 & Ratio of fine / coarse aggregate & 43 & $\%$ \\
\hline 18 & Specific gravity of Aggregate & 2670 & $\mathrm{~kg} / \mathrm{m}^{3}$ \\
\hline 19 & Total fresh Concrete & 2380 & $\mathrm{~kg} / \mathrm{m}^{3}$ \\
\hline 20 & Total Aggregate content & 1746 & $\mathrm{~kg} / \mathrm{m}^{3}$ \\
\hline 21 & Fine Aggregate content & 733 & $\mathrm{~kg} / \mathrm{m}^{3}$ \\
\hline 22 & Coarse Aggregate content & 1013 & $\mathrm{~kg} / \mathrm{m}^{3}$ \\
\hline
\end{tabular}

The proportion of mixture of normal concrete mixture above is also used to make by using bio enzyme. The composition of mix design per $\mathrm{m}^{3}$ of concrete materials are, cement $=409$ $\mathrm{kg} / \mathrm{m}^{3}$, water $=225 \mathrm{~kg} / \mathrm{m}^{3}$, fine aggregate $=733 \mathrm{~kg} / \mathrm{m}^{3}$, coarse aggregate $=1013 \mathrm{~kg} / \mathrm{m}^{3}$, and 
additive, type $\mathrm{A}=0 \mathrm{ml}$ (normal concrete), type $\mathrm{B}=200 \mathrm{ml}$, type $\mathrm{C}=400 \mathrm{ml}$, type $\mathrm{D}=600$ $\mathrm{ml}$, type $\mathrm{E}=800 \mathrm{ml}$, and type $\mathrm{F}=1000 \mathrm{ml}$.

\subsection{Compressive Strength.}

After testing and evaluating the average compressive strength of concrete of each type of concrete [2, 8-16], the following recapitulation of concrete compressive strength results, in table 2, and Fig. 2 shows the concrete compressive average strength of each mixture of concrete:

Table 2. Result of compressive strength

\begin{tabular}{|c|c|c|c|c|c|}
\hline $\begin{array}{l}\text { Name of } \\
\text { Sample }\end{array}$ & Sample & $\begin{array}{l}\text { Weight } \\
\text { (gram) }\end{array}$ & $\begin{array}{c}\text { Result } \\
\text { (kN) }\end{array}$ & $\begin{array}{l}\text { Result } \\
\text { (Mpa) }\end{array}$ & $\begin{array}{c}\text { Average of } \\
\text { 3(three) } \\
\text { samples }\end{array}$ \\
\hline \multirow{3}{*}{$\begin{array}{c}\text { Type A } \\
(0 \mathrm{ml})\end{array}$} & sample 1 & 12.82 & 516.70 & 29.25 & \multirow{3}{*}{28.58} \\
\hline & sample 2 & 12.94 & 501.70 & 28.40 & \\
\hline & sample 3 & 12.91 & 496.00 & 28.08 & \\
\hline \multirow{3}{*}{$\begin{array}{l}\text { Type B } \\
(200 \mathrm{ml})\end{array}$} & sample 1 & 12.65 & 500.80 & 28.35 & \multirow{3}{*}{29.47} \\
\hline & sample 2 & 12.72 & 523.30 & 29.63 & \\
\hline & sample 3 & 12.67 & 537.40 & 30.43 & \\
\hline \multirow{3}{*}{$\begin{array}{l}\text { Type C } \\
\text { (400 ml) }\end{array}$} & sample 1 & 12.93 & 590.10 & 33.41 & \multirow{3}{*}{33.58} \\
\hline & sample 2 & 12.91 & 597.70 & 33.84 & \\
\hline & sample 3 & 12.91 & 591.60 & 33.49 & \\
\hline \multirow{3}{*}{$\begin{array}{l}\text { Type D } \\
(600 \mathrm{ml})\end{array}$} & sample 1 & 12.87 & 614.40 & 34.79 & \multirow{3}{*}{33.79} \\
\hline & sample 2 & 12.91 & 594.50 & 33.66 & \\
\hline & sample 3 & 12.95 & 581.60 & 32.93 & \\
\hline \multirow{3}{*}{$\begin{array}{l}\text { Type E } \\
(800 \mathrm{ml})\end{array}$} & sample 1 & 12.97 & 577.60 & 32.70 & \multirow{3}{*}{32.99} \\
\hline & sample 2 & 13.00 & 568.10 & 32.16 & \\
\hline & sample 3 & 12.96 & 602.60 & 34.12 & \\
\hline \multirow{3}{*}{$\begin{array}{c}\text { Type F } \\
(1000 \mathrm{ml})\end{array}$} & sample 1 & 12.95 & 582.90 & 33.00 & \multirow{3}{*}{33.32} \\
\hline & sample 2 & 13.03 & 574.00 & 32.50 & \\
\hline & sample 3 & 12.98 & 608.40 & 34.45 & \\
\hline
\end{tabular}

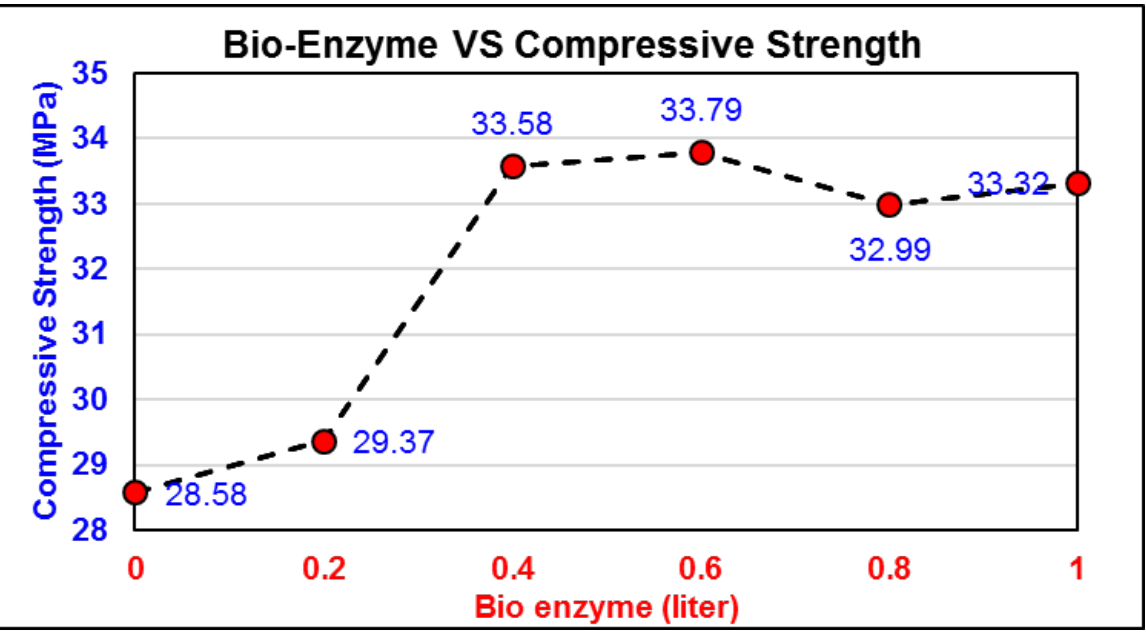

Figure 2. Bio Enzyme Content Vs Compressive Strength 


\subsection{Polynomial Regression Analysis.}

The analysis used to find the optimum level of bio enzyme mixture for compressive strength is the fourth degree of polynomial, or least quartic analysis. In this study the free $(x)$ variable is the variation of the bio enzyme's content and the dependent variable $(f(x))$ is the compressive strength of the concrete. The results of least quartic showing in fig. 3.

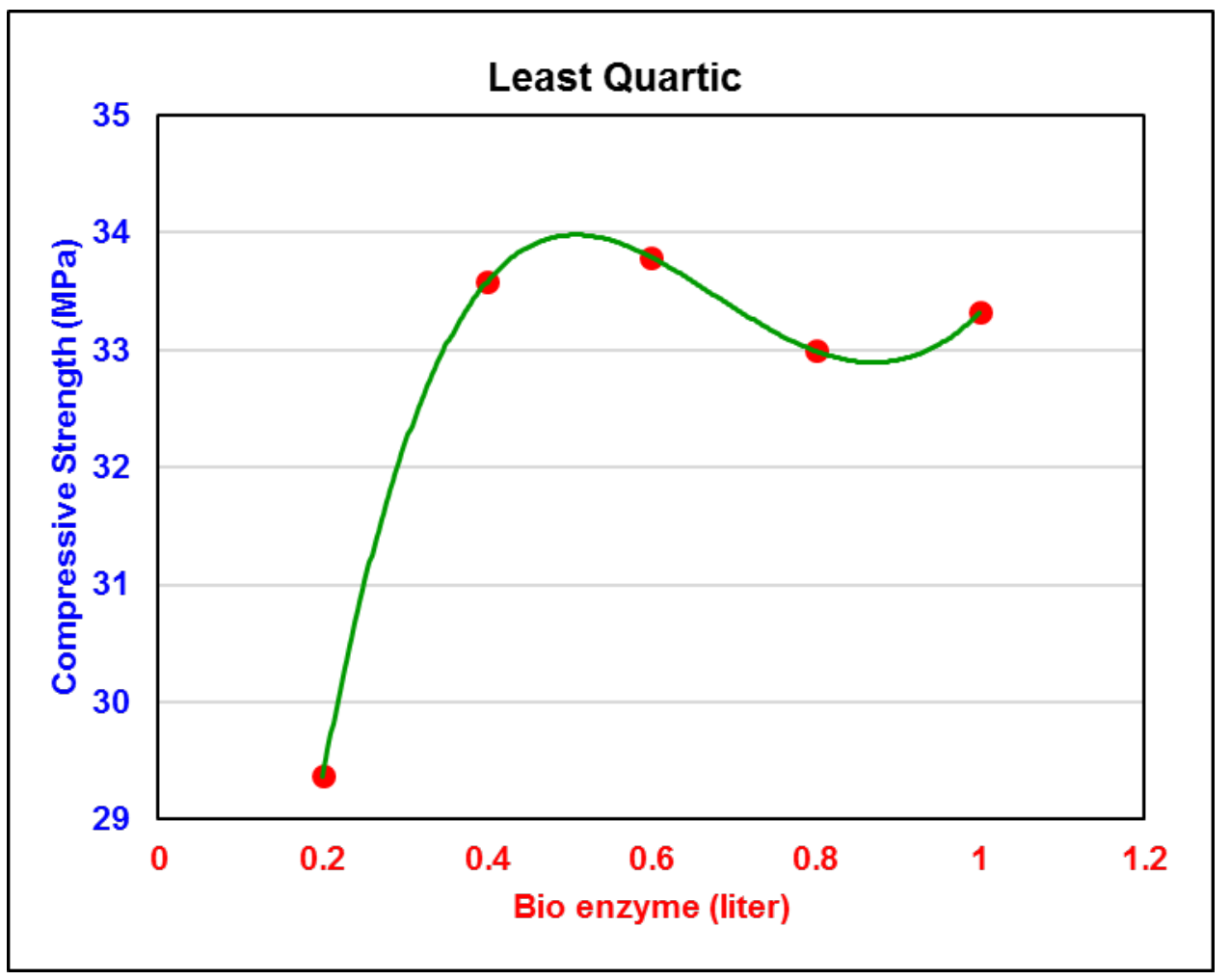

Figure 3. Least quartic / $4^{\text {th }}$ degree of Polynomial

The results of the five concrete model using $4^{\text {th }}$ degree polynomial regression (least quartic),

$$
f(x)=-17.9 x^{4}+95.321 x^{3}-145.044 x^{2}+83.007 x+17.938
$$

and $R^{2}=1$

derivative of equation (1) is

$$
f(x)^{\prime}=-71.6 x^{3}+285.96 x^{2}-290.08 x+83.007
$$

$x=$ bio enzyme (liter)

$f(x)=$ compressive strength $(\mathrm{MPa})$

to find maximum or minimum, $f(x)^{\prime}=0$, we get $x_{1}=0.509, x_{2}=0.872, x_{3}=2.613$, the obtained from the concrete quality normal concrete with $f c^{\prime}=25 \mathrm{MPa}$, substitution $x_{1}$ to equation (1) to find optimum value for $33.98 \mathrm{MPa}$, and the addition of $509 \mathrm{ml}$ bio enzymes. 


\section{Conclusion}

Based on the discussion that has been put forward in the previous chapter it can be concluded as follows:

1. Concrete $B$ with the addition of bio enzyme $200 \mathrm{ml} / \mathrm{m}^{3}$ there is increase of $3.1 \%$ to normal concrete (concrete A), concrete $C$ addition of bio enzyme $400 \mathrm{ml} / \mathrm{m}^{3}$ up $17,5 \%$ to normal concrete, concrete D addition of bio enzyme $600 \mathrm{ml} / \mathrm{m}^{3}$ up $18.2 \%$ of the normal concrete, the concrete $\mathrm{E}$ of the addition of bio enzyme $800 \mathrm{ml} / \mathrm{m}^{3}$ up $15.4 \%$ of normal concrete and decreased the quality of concrete $\mathrm{D}$ as much as $2.4 \%$, and $\mathrm{F}$ concrete addition of bio enzyme $1000 \mathrm{ml} / \mathrm{m}^{3} 3$ up $16.6 \%$ of normal concrete. It can be seen that D-concrete with the addition of bio-enzyme $600 \mathrm{ml} / \mathrm{m}^{3}$ is the right mixture of bio-enzyme to produce the compressive strength of concrete among other concrete variations.

2. The maximum $x_{l}$ based regression analysis is 0.509 litre or $509 \mathrm{ml}$, with a maximum compressive strength of $33.98 \mathrm{MPa}$. It can be concluded that the optimum mixture of bio-enzyme blends to increase the compressive strength of concrete is $509 \mathrm{ml} / \mathrm{m}^{3}$.

The acknowledgements of this research was funded by competitive grants, from Directorate Research and Community Service - Directorate General of Research and Research Development - Ministry of Research, Technology, and Higher Education Republic of Indonesia, 2017.

\section{References}

1. Aprilianti, S., Analisis Penggunaan Superplasticizer Type Napthalene dan Polycarboxilate, Tugas Akhir Teknik Sipil, Universitas Muhammadiyah Jakarta (2012)

2. Annual Book of ASTM Standards, Volume 04.02, Concrete and Aggregate (2002)

3. Badan Standarisasi Nasional, Tata Cara Pembuatan Rencana Campuran Beton Normal, SNI 03-2834-2000, adopsi SK-SNI T-15 1990-03, Jakarta (2000)

4. Bagio, Tony Hartono, Handout Perencanaan Campuran Beton Metode DoE British Standart with Microsoft Excel (2002)

5. Kong FK. and Evans RH., Reinforced and Prestressed Concrete, 3rd Edition, Chapman and Hall, London, UK (1994)

6. Mulyono, T., Teknologi Beton, Andi, Yogyakarta (2004)

7. Nawy, Edward G., Beton Bertulang: Suatu Pendekatan Dasar, Refika Aditama (1985)

8. SK SNI 03-2834-1992, Tata Cara Pembuatan Rencana Campuran untuk Beton Normal, (1992)

9. SK SNI 03-1968-1990, Metode Pengujian Tentang Analisis Saringan Agregat Halus dan Kasar (1990)

10. SK SNI 03-1969-1990, Metode Pengujian Berat Jenis dan Penyerapan Air Agregat Kasar, (1990)

11. SK SNI 03-1970-1990 Metode Metode Pengujian Berat Jenis dan Penyerapan Air Agregat Halus (1990)

12. SK SNI 03-1971-1990, Metode Pengujian Kadar Air Agregat (1990)

13. SK SNI 03-1972-1990, Metode Pengujian Slump Beton (1990)

14. SK SNI 03-1973-1990, Metode Pengujian Berat Isi Beton (1990)

15. SK SNI 03-1974-1990, Metode Pengujian Kuat Tekan Beton (1990)

16. SK SNI 03-2493-1991, Metode Pembuatan dan Perawatan Benda Uji Beton di Laboratorium (1991)

17. SNI 03-2834-2012, Tata cara perencanaan ketahanan gempa untuk struktur bangunan gedung dan non gedung (2012) 
18. Basoeki, Makno, Hands Out Diskusi Panel Peran Enzyme Mikroba dalam Peningkatan Kualitas Beton dan Produksi Beton dengan Reduksi Emisi CO2, Bogor (2000) 